\title{
PATHOPHYSIOLOGY OF PAIN AND USE OF OPIOIDS IN CATTLE
}

\author{
Felipe Gaia de Sousa ${ }^{1}$ \\ Rogério Carvalho Souza ${ }^{1}$ \\ Suzane Lilian Beier ${ }^{2}$ \\ Briza Sousa Barcelos ${ }^{1}$ \\ Kennedy José Souza Araújo ${ }^{1}$
}

\begin{abstract}
Pain control is an area that is currently gaining great importance, mainly for beef production. Determining the origin and causes of the painful process is a task that demands great attention from professionals, especially so that they can intervene in the best possible way. In addition to seeking to remove the factors that prompted them, they act in the prevention and treatment of the pain mechanism with the use of various drugs available on the market. The use of opioids has been the subject of studies as a pharmacological strategy for the control and management of animal suffering, a fact that induces serious losses and losses for bovine production, at the productive, reproductive and economic level. However, more and more studies are needed regarding the benefits they can provide to cattle, since there are some limitations such as cost and adverse effects.
\end{abstract}

Keywords: analgesia; welfare; pain control; production medicine

\section{FISIOPATOGENIA DA DOR E USO DE OPIOIDES EM BOVINOS}

\section{RESUMO}

O controle da dor é uma área que atualmente vem ganhando grande importância, principalmente para a bovinocultura. Determinar a origem e as causas do processo doloroso é uma tarefa que demanda grande atenção por parte dos profissionais, especialmente para que possam intervir da melhor maneira possível, além de buscar remover os fatores que incitaram, atuar na prevenção e tratamento do mecanismo da dor com uso de diversos fármacos disponíveis no mercado. O uso de opioides vem sendo alvo de estudos como estratégia farmacológica para controle e manejo do sofrimento animal, fato este que induz graves perdas e prejuízos para a produção bovina, a nível produtivo, reprodutivo e econômico. No entanto, faz-se necessário cada vez mais novos estudos a respeito dos benefícios que eles podem proporcionar aos bovinos, uma vez que existem algumas limitações como custo e efeitos adversos.

Palavras chave: analgesia; bem-estar; controle da dor; medicina de produção

\footnotetext{
${ }^{1}$ Pontifícia Universidade Católica de Minas Gerais - PUC MINAS - Betim-MG, Brazil. *Correspondência: fgaias@outlook.com

${ }^{2}$ Universidade Federal de Minas Gerais-UFMG - Belo Horizonte-MG, Brazil. suzanelb@yahoo.com.br
} 


\section{FISIOPATOLOGÍA DEL DOLOR Y USO DE OPIOIDES EN BOVINOS}

\section{RESUMEN}

El control del dolor es un área que está cobrando gran importancia en la actualidad, especialmente para la ganadería. Determinar el origen y las causas del proceso doloroso es una tarea que requiere gran atención por parte de los profesionales, especialmente para que puedan intervenir de la mejor manera posible, además de buscar remover los factores que los incitaron, actuando en la prevención. y tratamiento del mecanismo del dolor mediante el uso de diversos fármacos disponibles en el mercado. El uso de opioides ha sido objeto de estudios como estrategia farmacológica para el control y manejo del sufrimiento animal, hecho que induce graves pérdidas y pérdidas para la producción bovina, a nivel productivo, reproductivo y económico. Sin embargo, se necesitan cada vez más estudios sobre los beneficios que pueden brindar al ganado, ya que existen algunas limitaciones como el costo y los efectos adversos.

Palabras clave: analgesia; bienestar; control de dolor; medicina de producción.

\section{INTRODUCTION}

Pain can be understood as a physiological response of the organism to some event, be it traumatic, inflammatory, infectious, among others, being recognized for the first time as the fifth vital sign in 1995, by James Campbell, president of the American Society of Pain, with the objective of making health professionals aware of the adequate treatment of pain. Thus, the organism has a series of episodes in a neurofunctional scheme so that the pain is recognized. Right after the inciting event, through structures known as neuroreceptors, the pain is transformed into electrical impulses that will be directed and modulated to the brain region so that the pain is perceived $(1,2)$.

Pain treatment is based on systemic, local and / or regional therapy. Among professionals, adequate pain management is not yet a consensus, since therapies vary considerably, and the decision to use analgesics for particular conditions seems to have a dichotomous distribution, with professionals choosing to use analgesics for all cases or for none (3). Non-steroidal anti-inflammatory drugs (4), opioids (5), local anesthetics, alpha-2 agonists and unconventional drugs, such as ketamine, are the most used against pain (3). In addition, there are those who believe that animals do not have a cognitive or emotional response, and therefore could not feel pain. However, several studies indicate that animals have the same neuronal processing of pain recognition, conduction and modulation as humans $(6,7)$.

It is also known that pain is a parameter included in animal welfare guidelines, being one of the cares that ensure quality of life (QL), and an animal in pain can have several consequences, such as immunosuppression, reduced appetite, weight loss, reduced productivity, among others (7-10). Brazil is one of the leading countries in cattle breeding, and procedures such as dehorning, cesarean sections, castration, among others, are routine in both beef and dairy creations. In addition, animals are subject to various situations that can trigger the phenomenon of pain (11), such as laminitis (12-14), torsion of the abomasum, accidents, fights, ingestion of a foreign body, among others $(3,15,16)$. Thus, the presence of a trained veterinarian to recognize pain, treat it correctly and change management (4) in order to prevent pain and improve animal welfare $(13,14,17)$, and consequently improve and increase productivity, is of paramount importance. 
Opioids interact by reversible combination with specific receptors, opioids and nonopioids, and endorphinic receptors (brain, spinal, autonomic, gastrointestinal, cardiac and renal myenteric), which are important in neuromodulation of pain, behavior, muscle tone and gastrointestinal motility. They produce varied effects such as sedation, analgesia, excitation; variables according to species, individuals and physiological and pathological conditions. They are classified according to analgesic activity and the possibility of inducing dependence, as pure agonists (meperidine, morphine, fentanyl); partial agonists (butorphanol), and those that have agonist analgesic activity and can, to some extent, antagonize the effects of pure agonists and pure antagonists (naloxone) that have no activity when used alone, antagonizing the effects of agonists (18).

\section{PAIN}

According to the International Association for the Study of Pain (IASP), "pain is an unpleasant sensitive and emotional experience, associated with, or similar to that associated with, a real or potential tissue injury" (19). Penning (20) already stated that pain can be considered as a protective strategy derived from some triggering event that, when not verified and corrected, induces the animal to a state of exacerbation of painful sensitivity, providing a lasting sensation. According to Fein (21), "pain is an unpleasant emotional experience that usually accompanies nociception". Thus, pain is something that represents and encompasses multiple variables (6), thus, the evaluation of only one of them cannot be used as a defining factor (2).

Some authors argue that pain is a physiological process and extremely necessary because it concerns the ability of cells and the body to respond in the face of a painful event, thus, it is considered as a survival mechanism. However, pain when present can induce animals to a series of physiological changes that can threaten the quality of life and survival $(2,22)$. Some animals, when subjected to painful events, modify their behavior (7) and, in view of that, it is possible to observe that there is a reduction in food and water intake. Consequently, there is severe anorexia that can evolve to intense weight loss and body score, in addition to mild dehydration tending to severe, depending on the severity of pain and water consumption.

Among the various ways of assessing pain, observations on the behavior of cattle can be very useful and necessary (2). Thus, any behavioral change that the animals present, one should suspect the presence of some associated painful phenomenon (23). Thus, behavioral changes can have numerous causes related to pain, such as devices for reducing, spreading or intensifying pain.

Due to the great pathophysiological changes of the diseases and the severity that affect the animals, pain can be classified according to the type of process. Thus, there are two types of painful event: acute pain and chronic pain. Acute pain is characterized by processes that arise quickly after the triggering event with the presence of inflammatory and painful mediators, being characterized by real tissue damage. In contrast, the chronic process is detailed with something multidimensional, that is, there are several factors that interact with each other and cause the stimulus to persist even for long periods after the initial event. Therefore, chronic pain can be considered as a morbid state and classified as a pathology, being treated differently from acute pain. Treating pain and looking for the phenomena that cause it can be an arduous but necessary task. Each day, the importance of identifying and establishing therapeutic protocols becomes more evident due to the intense consequences that the painful process can provide to animals. Therefore, the use of multimodal therapies, with quality of life management and analgesic and sedative drugs, are of paramount importance and of great value. 


\section{PATHOPHYSIOLOGY OF PAIN}

The pathophysiology of pain is considered as a set of changes that occur and that affect innumerable organic segments and that depends on innumerable innervations for it to occur and be properly transmitted $(22,24,25)$. According to Fein $(21)$, "nociception refers to the signals that reach the central nervous system (CNS) resulting from the activation of specialized sensory receptors, called nociceptors, which provide information about tissue damage". Nociceptors are located in various regions of the organism, such as body surface, membranes, tissues, mucous membranes, bone and joint regions, among others (21,24-27). The process occurs as follows: the nociceptors of the sensory fibers after the identification of the stimulus promote the conversion of them into action potentials (electrical signals) (25). In this way, they are propagated to the dorsal horn of the medulla (DHSC) to be irradiated to the trunk and the brain, where painful perception occurs $(22,27)$.

The nociception mechanism depends on specialized structures (22), so it has a system known as a "chain of three neurons" (21). First order ( $1^{\text {st }}$ order $)$ neurons, or afferent primaries, are located on the periphery and are responsible for the electrical transformation process (action potential) of environmental stimuli, as well as their conduction to second order $\left(2^{\text {nd }}\right.$ order) neurons, or driving, located in the DHSC region $(21,25,27,28)$. These, boost the action potential to third order ( $3^{\text {rd }}$ order), or supraspinatus neurons, identified in regions such as bulb and bridge, in addition to the midbrain, hypothalamus and thalamus $(21,28)$. They lead the action potential to cortical and subcortical regions where painful perception occurs $(21,28)$.

Thus, right after the painful stimulus occurs, the sensory fibers of the nociceptors stimulate the transduction process, that is, they convert the environmental stimulus into an action potential (22). The electrical signals are conducted (transmission) along the fibers to the region of the DHSC (27), later modulated (modulation) and forwarded to the brainstem / brain (projection). Through the cortical and subcortical regions, painful assimilation (perception) occurs with stimulation of protective reflexes (21) (Figure 1).

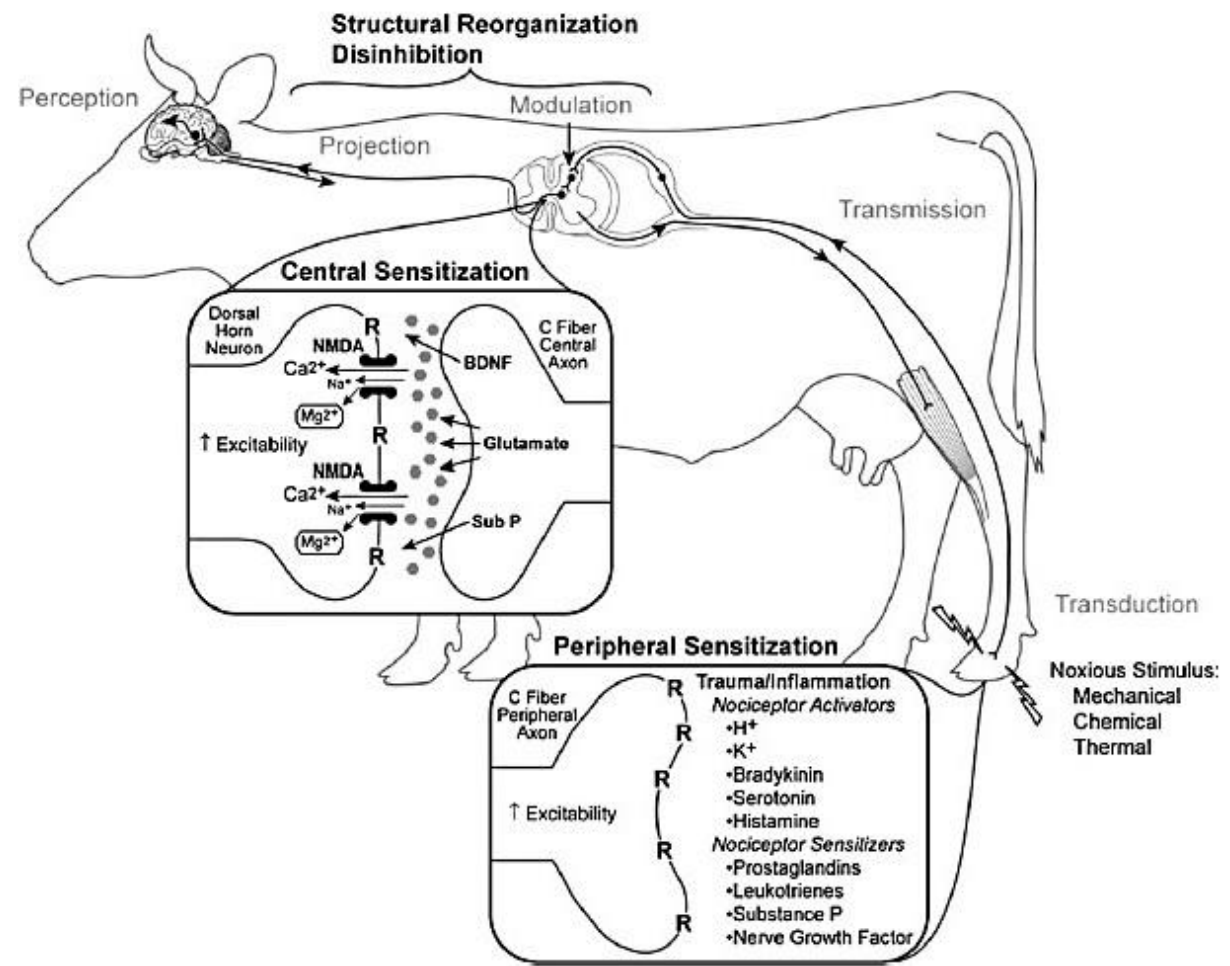

Figure 1. Neurofunctional scheme of painful assimilation. Through painful stimulation, through nociceptors, transduction occurs, which converts environmental signals into electrical potentials. They 
are conducted and modulated in the regions of the dorsal horn (DHSC), brainstem and brain, and through cortical and subcortical regions, painful perception occurs with stimulus for protective reflexes. Consider: $\mathrm{Ca}^{2+}$ - calcium ion; $\mathrm{Mg}^{2+}$ - magnesium ion; $\mathrm{Na}^{+}$- sodium ion; $\mathrm{H}^{+}$- hydrogen ion; $\mathrm{K}^{+}$- potassium ion; $\mathrm{R}$ - receiver; NMDA - N-methyl D-Aspartate; BDNF - brain-derived neurotrophic factor; Sub P - substance P. Anderson and Muir (15). 


\section{TRANSDUCTION}

The transduction mechanism is based on the stimulation of sensory nerve fibers through various phenomena, whether they are thermal, mechanical and / or chemical $(21,25)$. After stimulation, there is a modification of environmental stimuli in action potentials (electrical impulse) that can be observed in the region of peripheral receptors of $1^{\text {st }}$ order neurons (25). In conjunction with previous changes, the body responds with various physiological changes such as increased local blood influx and muscle contractility, pressure changes, among others.

Among the various types of nociceptive nerve fibers (25), only $\mathrm{C}$ and $\mathrm{A}$ - delta $(\mathrm{A} \delta$ ) fibers are related to the painful process $(21,22,24,29)$. They present speeds in the dissipation of the nervous impulse, the A $\delta$ fibers being responsible for pain of a fast, acute and strong character, while the $\mathrm{C}$ fibers are slow and continuous $(21,24,25,30)$.

When tissue damage occurs, chemical mediators are released at the local and systemic level, and when associated with neurotransmitters, they can promote neuronal changes that result in an increase or reduction in sodium $\left(\mathrm{Na}^{+}\right)$influx neuronal (action potential) (26). Among the chemical mediators, we can mention the substance $\mathrm{P}$ with the function of helping the inflammatory and nociception processes, and cytokines whose attribution is to modulate the cellular response, in addition to both providing changes in the excitatory character of the original fibers sensory and sympathetic (22,31). In addition, other inflammatory mediators $(22,24)$ such as platelets, macrophages and mast cells are released and together with other substances such as cytokines, amino acids, products obtained from the arachidonic acid cascade, among others, form a compound known as "sensitizing soup" or "inflammatory soup" (31,32).

With regard to this, mediators perform better functions when together (synergism) and therefore, they can modulate the way the primary response in the afferent neuron will occur after immediate stimulation. Thus, due to the synergism present, nociceptors become more sensitive to low stimulations (drop in the threshold), that is, there is no need for large stimuli to be activated - primary hyperalgesia (27,31). According to Fein (21), "some of the registered neurons are differentiated because they have a relatively high activation threshold, for example, they can only be activated by intense stimuli - mechanical, thermal or chemical irritant - that are potentially harmful to tissues. These high-threshold neurons are considered the primary afferent nociceptors".

Subsequently, the reduction of nociceptive sensitization, secondary hyperalgesia occurs, thus, the spinal nerves and the brain become sensitized with considerable changes (31). Thus, after the institution of the sensitizing event, the primary afferent nociceptors are excited and the tactile signal is recognized in painful (allodynia) $(27,30,31,33)$.

\section{TRANSMISSION}

Transmission consists of the dissipation of nerve impulses through peripheral nerve bundles, which starts at nociceptors to the central system (DHSC) through the communication of association structures (interneurons) of $1^{\text {st }}$ order neurons with the gray matter of the spinal cord (25). According to Alimura and Tognoli (25), the action potentials derived from nerve, sensory and motor impulses are guided to the medulla by nerve bundles, thus, after the activation of afferent nerves in the extremities, the stimulus is converted and dissipated. Regarding the classification of $1^{\text {st }}$ order neurons, it is possible that they are non-nociceptive (harmless stimuli), nociceptive (harmful stimuli) and wide dynamic spectrum - WDR (harmless and harmful stimuli) (24). 


\section{MODULATION}

Modulation consists of ensuring stability between peripheral stimulation and inhibitory/excitatory control. Thus, "modulation occurs through endogenous descending analgesic systems, which modify nociceptive transmission" (34). Among the various excitatory receptors involved, glutamate (GLU) (5) seems to have greater importance despite the fact that the amino acid aspartate peptides (eg vasoactive intestinal peptide), substance $\mathrm{P}$, cholecystokinin (CCK), nitric oxide (NO), prostaglandins (PG) (35) and adenosine triphosphate (ATP) may be involved in the process $(22,25,33)$. However, in the case of inhibitors, the most associated receptors are gamma-aminobutyric acids (gabaergic - GABA) $(1,36)$, opidergic, cholinergic and glycinergic acids (24).

One of the main mechanisms that enabled the knowledge of the modulatory phenomenon occurred through the "gate theory" developed by Melzack and Wall (37). The respective theory concerns the activation of WDR interneurons by means of nociceptive and non-nociceptive fibers. While the previous fact occurs, the A - beta $(A \beta)$ fibers promote the activation of inhibitory communicating neurons (interneurons) in the DHSC that bind with the WDRs, and that are inhibited by $\mathrm{A} \delta$ and $\mathrm{C}$ fibers (37). The gate works so that the nonnociceptive fibers close the mechanism while the nociceptive fibers open (37).

The previous theory can be exemplified as follows: shortly after the occurrence of abrasions on the skin, the coarse fibers $(\mathrm{A} \beta)$ propagate impulses that are noticed, but do not imply painful sensations (closed gate). However, from the moment that the process is chronic and with greater vigor, a greater number of receptors are stimulated, allowing the gate to open (interneuron inhibition) due to the overload of $\mathrm{A} \beta$ fibers (38). Thus, the $\mathrm{A} \delta$ and $\mathrm{C}$ (thin) fibers lead the process to central sensitization with painful manifestation (39).

\section{PROJECTION}

The projection is based on conducting the information that has been modulated in the medullary to the cerebral region by means of nociceptive structures composed of axonal branches from the DHSC (24). Through projection neurons, information is dissipated through pathways that innervate regions such as the limbic system and reticular formations that are fundamental to the nociceptive phenomenon (25).

\section{PERCEPTION}

Perception is the integration of nociceptive information, that is, the awareness and emotional experience of pain. The perceptual phenomenon encompasses the assimilation, processing and discernment of the painful event to $3^{\text {rd }}$ order neurons. Countless brain segments are involved in the process, such as the thalamus, the cortical area and the limbic system, which communicate through communicating neurons in order to generate increasingly assimilated and structured responses (25).

\section{MANAGEMENT AND STRATEGIES FOR PAIN CONTROL}

The management and control have been the subject of intense studies due to the great need to prevent and reduce their appearance, since they can cause serious consequences to animals (11). When uncontrolled, the pain can evolve to situations of high sensitivity to pain (hyperalgesia) (7), in addition to providing the animal with a painful sensation for long periods, and causing greater physiological consequences due to the chronification of the process. 
In the face of constant painful stimuli, there is a change in systemic health and animal behavior, which causes changes in the quality and welfare of cattle $(13,14,17,23)$. And, if the disease is intense and progressive, it is possible to observe that some animals evolve to death, the same being associated with the low quality of life and clinical presentation. For pain management and control to be carried out effectively, it is necessary to identify the cause of the pain (11,34). In addition, they state that after prior knowledge of the pathological mechanisms that justify its existence, together with the presence of inflammatory and pain mediators, the therapeutic protocol can be designed and executed in order to obtain the desired effect.

The first step in pain management and control is to identify it $(11,12)$. There is still no gold standard for assessing pain, and it is known that the expression of pain varies according to age, species, race and individual temperament. In addition, debilitating diseases and external agents such as stress, anxiety and fear also influence the expression of pain in animals $(3,6)$. Clinical parameters can be used, such as heart rate (HR), respiratory rate (RF), blood pressure and temperature, as well as hormonal indicators, such as cortisol and catecholamines, but they are not viable in cases of herds and production medicine. Thus, behavioral parameters are more interesting, assessing state of consciousness and temperament, movement, muscle tone, facial tension, vocalization, breathing pattern, among others $(3,40)$. Regarding treatment, Canozzi et al. (16) conducted a survey with Brazilian veterinarians, and demonstrated that the tendency of professionals is to prioritize the cost of the analgesic (12), and do not evaluate the benefit of pain relief in regarding to increased productivity; and therefore it is interesting to teach about the importance and on the various forms of pain management and control on farms.

\section{OPIATES}

Opioids are used to control pain and thus ensure welfare. Natural compounds and synthetic derivatives interact by reversible combination with specific receptors, opioids and non-opioids, and endorphinic receptors (brain, spinal, autonomic, gastrointestinal, cardiac and renal myenteric) (18), important in the neuromodulation of pain, behavior, muscle tone and gastrointestinal motility (25). They produce varied effects such as sedation, analgesia, excitation, which are variable with the species, individual, physiological and pathological conditions $(6,18)$. However, opioids can produce hyperalgesia and collateral effects (time and dose-dependence) $(5,30)$.

\section{PHARMACOLOGY AND PHARMACOKINETICS OF OPIOIDS}

The pharmacokinetics of opioids are of paramount importance, especially to establish, according to Kukanich and Wiese (41), "the speed and degree of absorption of a drug, the plasma concentrations obtained with a given dose administered to a given species or population of patients, the permanence of the drug after the administration of a dose and, sometimes, the possibility of drug interactions". Opioids can be administered by several routes, including per os (PO), intramuscular (IM), subcutaneous (SC) and intravenous (IV). However, it is known that drugs when administered by PO undergo hepatic metabolism so that they become active (30), which reduces its bioavailability and the expected post-use effects. The exception of some considered as prodrugs that after they pass through the liver become active. In the case of the IM and SC pathways, the absorption time is faster and bioavailability is greater when compared to PO, thus, there is more drug available to produce the desired effect (41). 
Opioids act mainly on the central nervous system (CNS) and for that, it is necessary that they enter the brain region to produce the effects of sedation and analgesia with the aid of glycoprotein P. In addition, the distribution may be influenced by the blood flow of the region, so that the lower the blood supply to tissues and organs, the less the pharmacological effects of opioids. When administered via bolus, they quickly reach the minimum plasma concentration to produce effects, however, as they are metabolized and excreted, the respective concentration decreases. Most of the opioids are metabolized via the hepatic parenchyma, using the phases of metabolism I and / or II, considering that some substances are considered as prodrugs. After the process of metabolization and production of the effect, they are eliminated mainly via the kidney due to the property of being water-soluble, but they also present fecal elimination by bile excretion (41).

\section{RECEPTORS AND TYPES OF OPIOIDS}

Among the various types of opioid receptors, mu $(\mu)$, kappa $(\kappa)$ and delta $(\delta)$ can be mentioned $(18,29,30)$. According to Kukanich and Wiese (41), "there are variants of the $\mu$ opioid receptor, which may explain the relative sensitivity of a species to the adverse effects of opioids, including dysphoria, or the relative insensitivity to the adverse effects of opioids". This fact may be related to the phenomenon of alternative "splicing" that induces structural and functional changes in the receptors (42).

In addition, the authors still claim that they can be found in various regions of the body such as the spinal brain, trigger zone, gastrointestinal system, among other regions (41). They are classified according to analgesic activity and the possibility of inducing dependence, as pure agonists; partial, and those that have agonist analgesic activity and can, in a way, antagonize the effects of pure agonists and antagonists that have no activity when used alone, antagonizing the effects of agonists $(6,25)$.

\section{USE AND EFFECTS OF OPIOIDS FOR CATTLE}

According to Anderson and Edmonson (43), opioids can be used in several ways, which in part can contribute to reduce the cardiovascular effects they provide. However, some authors claim that the use of opioids is lower when compared to other classes due to the cost they have (44). The authors also add that the most used drug in the class is butorphanol tartrate (45) at a dose of $0.02-0.04$ milligrams (mg) per kilo (kg), administered intravenously (IV) or subcutaneous tissue (SC) for periods of $4-6$ hours (h) (43). Butorphanol is an opioid agonist antagonist that provides potential analgesia, with less adverse effects when compared to a complete agonist, such as morphine (45). In addition, morphine $(0.05-0.1 \mathrm{mg} \mathrm{kg}$, via SC, $4-12 \mathrm{~h}$ ) and buprenorphine $(0.005-0.01 \mathrm{mg} / \mathrm{kg}$, via SC, $6-12 \mathrm{~h})$ can also be used, but with varied side effects. It is noteworthy that the adverse effects presented by the animals after the administration of any medications, in quantity and severity, depend on a series of factors such as greater sensitivity to the drug, route of application, among others (Table 1).

According to Sunilchandra et al. (18), the use of opioids in cattle "produce hyperactivity in ruminants, and particularly chewing behaviour". The amount of medication needed for ruminants to be immobilized varies according to some factors, such as weight and size of the animal. Thus, the dosage is inversely proportional to the size of the animal, so the smaller the ruminant, the higher the doses will be necessary (18). For Mathews et al. (6), "opioid drugs should be titrated to effect to minimize the risk of respiratory compromise."

Drugs used in the form of transdermal patches, especially fentanyl-based $(0.05-0.1 \mathrm{mg}$ $/ \mathrm{kg}$ ) can be useful with effects lasting around 3 days (Figure 2). However, authors claim that further studies are needed on the use of fentanyl citrate in cows (46). Another option that has 
been discussed and researched by some authors is based on the strategy known as ketamine stunning. This alternative consists of the application of ketamine associated with butorphanol and xylazine, and according to the authors, they present benefits to the animal by guaranteeing reduced sensitivity to pain, chemical control and unconsciousness (47). According to Anderson and Edmondson (43), "the combination of an opioid $(0.025 \mathrm{mg} / \mathrm{kg}$ butorphanol), $\alpha 2$ agonist (xylazine $0.05 \mathrm{mg} / \mathrm{kg}$ ) and neuroleptic (ketamine $0.1 \mathrm{mg} / \mathrm{kg}$ ) appears to create an altered state of consciousness that has been very beneficial when performing surgical procedures on fractured cattle or suffering from extreme pain as a result of disease condition".

Table 1. Table with recommendations for dose, route and interval of administration of opioids for cattle. Adapted by Anderson and Edmondson (43). The doses of the drugs above follow those recommended by Anderson and Muir (15) and Coetzee (44).

\begin{tabular}{|l|c|c|c|}
\hline \multicolumn{1}{|c|}{ Opioids } & Recommended dose & Route of administration & Interval \\
\hline \multirow{2}{*}{ Butorphanol } & \multirow{2}{*}{$0,02-0,05 \mathrm{mg} / \mathrm{kg}$} & $\mathrm{IV}$ & $2-4 \mathrm{~h}$ \\
\cline { 2 - 4 } & $0,005-0,01 \mathrm{mg} / \mathrm{kg}$ & $\mathrm{SC}$ & $6-8 \mathrm{~h}$ \\
\hline Buprenorphine & $0,05-0,5 \mu \mathrm{g} / \mathrm{kg}$ & $\mathrm{IM}$ & $6-12 \mathrm{~h}$ \\
\hline Fentanyl & $3,3-4,4 \mathrm{mg} / \mathrm{kg}$ & $\mathrm{SC} / \mathrm{IM}$ & $72 \mathrm{~h}$ \\
\hline Meperidine & $0,5-1 \mathrm{mg} / \mathrm{kg}$ & $\mathrm{IV}$ & - \\
\hline \multirow{2}{*}{ Morphine } & $0,05-0,1 \mathrm{mg} / \mathrm{kg}$ & Epidural & $24 \mathrm{~h}$ \\
\cline { 2 - 4 } & &
\end{tabular}

*Consider: $\mathrm{mg} / \mathrm{kg}$ - milligrams per kilo; $\mu \mathrm{g} / \mathrm{kg}$ - micrograms per kilo; IV - intravenous; SC - subcutaneous; IM - intramuscular; $\mathrm{h}$ - hours. Note: None of these drugs have been approved for use in cattle in the United States. Meat and milk retention times should be estimated with caution.

Tramadol is an $\mu$ agonist opioid with central analgesic action $(30,48)$ that has been used for management in cattle. According to studies, the drug hardly promotes serious cardiorespiratory changes even though it is used in high doses, and situations of reduced intestinal transit and pharmacological dependence are less frequent (18). However, according Bravo et al. (48), "tramadol may have other advantages over opioids, including less withdrawal reactions and less respiratory depression than conventional opioids at equivalent doses". In the case of horses, the epidural use of the drug promotes analgesia in the sacrum and perineum region (49), and in humans, preoperative SC applications guarantee analgesic reduction in the post-surgical period and control pain for a longer time when compared to the isolated use of lidocaine (50). The epidural can be a problem when it is necessary for the animal to be in season to perform the surgery, although it can be done to guarantee numbness in the posterior regions such as rectum and genitourinary (51).

Baniadam et al. (52) conducted a study evaluating the analgesic efficacy of tramadol when administered epidurally in cattle, since research on the drug is scarce. The study used 5 healthy females, with a mean age of $4.8 \pm 0.8$ years, and 3 doses of tramadol $(1,2$ and $3 \mathrm{mg} /$ $\mathrm{kg}$ ) administered to each cow with 1 week difference between applications. Thus, each animal was subjected to a dose of the drug each week. The authors evaluated using scales $(0-3)$ analgesia, ataxia and sedation before (5 minutes - $\mathrm{min})$ and after (120 min) the administration of the drug, in addition to measuring heart rate (HR) and respiratory rate (RF), temperature $\left({ }^{\circ} \mathrm{C}\right)$ and motility following the same time previously mentioned. The desensitization period was based on dose-dependence, thus, cows that received higher concentrations of tramadol, had longer periods of analgesia ( $1 \mathrm{mg} / \mathrm{kg}-18 \mathrm{~min} ; 2 \mathrm{mg} / \mathrm{kg}-60 \mathrm{~min} ; 3 \mathrm{mg} / \mathrm{kg}-92 \mathrm{~min}$ ). In addition, animals that received doses above $2 \mathrm{mg} / \mathrm{kg}$ presented with small / mild sedation and ataxia. In relation to the other physiological parameters evaluated, there were no differences when the drug was administered. 
Naeine et al. (53) carried out a study with the objective of verifying the clinical and analgesic effects of some drugs when administered via the epidural route in cattle such as morphine, fentanyl, methadone, lidocaine, lidocaine associated with epinephrine and a control group with saline solution. For the study were used 5 females of the breed Hostein-Frisia, approximately 2 - 3 years old. Each week, one drug of the aforementioned drugs was administered to the cows, and at the end of the process all animals had received all drugs with doses calculated by body weight. The medications followed the following schedule: lidocaine hydrochloride $(0.22 \mathrm{mg} / \mathrm{kg}$ body weight); lidocaine hydrochloride with epinephrine $(0.22 \mathrm{mg}$ / $\mathrm{kg}$ body weight); morphine ( $0.1 \mathrm{mg} / \mathrm{kg}$ body weight); fentanyl ( $0.005 \mathrm{mg} / \mathrm{kg}$ body weight); methadone $(0.1 \mathrm{mg} / \mathrm{kg}$ body weight); saline solution $(0.2 \mathrm{ml} / \mathrm{kg}$ body weight of $0.9 \%$ sodium chloride). They also report that the volume of each application was $20 \mathrm{ml}$, using sterile saline as a diluent. HR, RF, pulse and cardiac rhythm were assessed with each administration, but there were no significant changes. The authors noticed that there was no sedation after the use of opioids (morphine, fentanyl, methadone) and saline.

Nogueira et al. (54) conducted a study to compare the analgesic effects of morphine and tramadol in cattle with pharmacologically induced arthritis and synovitis by a single application of amphotericin B. Six healthy, whole cattle between $24-30$ months and an average weight of $230 \pm 13.03 \mathrm{~kg}$. Two types of treatment were performed, the first of which was carried out with morphine (GM) on the right posterior limb and 20 days later, treatment with tramadol (GT) was carried out on the contralateral limb. The GM was based on the application of $0.5 \mathrm{mg} / \mathrm{kg}$, IM, being made 2 applications with an interval of $6 \mathrm{~h}$ each. After 20 days, $1.8 \mathrm{mg} / \mathrm{kg}$ IM of GT in a single dose was applied to the left posterior limb. The authors evaluated the animals for $27 \mathrm{~h}(1$ evaluation every $3 \mathrm{~h})$ according to "physiological parameters, ambulation and pedometric activity". Nogueira et al. (54) noted that even after the administration of the two types of treatment, mobility difficulties were still present, leading them to conclude that the doses used "were unable to interfere in the attenuation of the degree of claudication at the moment of maximum painful stimulation, facing to the experimental model of orthopedic pain ".

Silva et al. (55) conducted studies comparing the effects of administering xylazine and tramadol via the epidural route in cattle. For the respective study, 24 cows were used, aged around 2 years and with an average weight of $357 \pm 38.7 \mathrm{~kg}$. The animals were segregated, in a random and equal way, in 3 groups: GX - xylazine group $(0.05 \mathrm{mg} / \mathrm{kg}$ of $2 \%$ xylazine); GT - tramadol group $(1 \mathrm{mg} / \mathrm{kg}-50 \mathrm{mg} / \mathrm{ml})$ and GC - saline group $(0.9 \%$ solution; total volume 6 milliliters - $\mathrm{ml}$ ). Clinical parameters $\mathrm{HR}, \mathrm{RF}$, systolic blood pressure (SBP), $\mathrm{T}^{\circ} \mathrm{C}$ and ruminal motility were evaluated. Analgesia was classified according to the scale after stimulus (needle) varying from 1 - 4, from normal response to pain to complete analgesia. Sedation was also graded from 0 - 3, ranging from absent to severe, with assessments every $30 \mathrm{~min}$ for a total time of $180 \mathrm{~min}$. Of the clinical parameters evaluated, there was only a slight reduction in ruminal motility, however, without clinical importance. When the 3 groups were compared according to the variables analgesia and sedation, the GX showed better results than the GT, which can be explained by the effect of the drug on $\alpha 1$ receptors to reduce its rescue by the vessels (55).

\section{FINAL CONSIDERATIONS}

Pain has always been discussed in the field of animal medicine and is now increasingly important due to the correlation between the existence of the painful process with productive and reproductive changes, in addition to the financial ones imposed on producers. Thus, the welfare and living conditions of cattle are increasingly the target of intense studies in order to mitigate or prevent the appearance of any painful mechanism that may affect the 
quality of life of the animals. Several strategies are already well established, such as the use of $\alpha 2$ agonists, analgesics and anti-inflammatories. The use of opioids for pain control has been taking increasing proportions as an alternative form of use, however, further studies involving the use of the class in the treatment and especially prevention of the painful process are still needed. Research shows that the use of certain types of opioids such as tramadol in some anesthetic procedures such as caudal epidurals can be beneficial (dose-dependence). In addition, lower doses of opioids for cattle may not guarantee sufficient sedation and analgesia. However, further work is still needed on the use of other opioids, especially epidural via cattle, which would be of great value and practicality in the field.

\section{REFERENCES}

1. Lagomarsino VN, Kostic AD, Chiu IM. Mechanisms of microbial - neuronal interactions in pain and nociception. Neurobiol Pain. 2020;9:10056. doi: 10.1016/j.ynpai.2020.100056.

2. Nunes MHV, Pacheco AD, Wagatsuma JT. Recognition and assessment of pain in cattle: Review. Pubvet. 2021;15(6):1-12. doi: 10.31533/pubvet.v15n06a831.1-12.

3. Millman ST. Behavioral responses of cattle to pain and implications for diagnosis, management, and animal welfare. Vet Clin North Food Anim Pract. 2013;29(1):47-58. doi: 10.1016/j.cvfa.2012.11.007.

4. Wagner BK, Nixon E, Robles I, Baynes RE, Coetzee JF, Pairis-Garcia MD. Non-steroidal anti-inflammatory drugs: pharmacokinetics and mitigation of procedural-pain in cattle. Animals. 2021;11(2):282. doi: 10.3390/ani11020282.

5. Richebé P, Capdevila X, Rivat C. Persistent postsurgical pain - pathophysiology and preventative pharmacologic considerations. Anesthesiology. 2018;129(3):590-607. doi: 10.1097/ALN.0000000000002238.

6. Mathews K, Kronen PW, Lascelles D, Nolan A, Robertson SA, Steagall PVM, et al. WSAVA guidelines for recognition, assessment and treatment of pain. J Small Anim Pract. 2014;55(6):E10-68. doi: 10.1111/jsap.12200.

7. Whay HR, Shearer JK. The impact of lameness on welfare of the dairy cow. Vet Clin North Am Food Anim Pract. 2017;33(2):153-64. doi: 10.1016/j.cvfa.2017.02.008.

8. American college of veterinary anesthesiologists' position paper on the treatment of pain in animals. J Am Vet Med Assoc [Internet]. 1998 [cited 2021 Apr 10];213(5):628-30. Available from: https://pubmed.ncbi.nlm.nih.gov/9731254/

9. Crook A. Introduction: pain: an issue of animal welfare. In: Egger Cm, Love L, Doherty T. Pain management in veterinary practice. Ames: John Wiley \& Sons; 2014. Chap 1, p. 1-8.

10. Ryan S, Bacon H, Edenburg N, Hazel S, Jouppi R, Lee N, et al. WSAVA animal welfare guidelines for veterinary practitioners and veterinary teams. J Small Anim Pract. 2019;60(5):1-46. doi: 10.1111/jsap.12998.

11. Robles I, Arruda AG, Nixon E, Johnstone E, Wagner B, Edwards-Callaway L, et al. Producer and veterinarian perspectives towards pain management practices in the US cattle industry. Animals. 2021;11(1):209. doi: 10.3390/ani11010209.

12. Becker J, Reist M, Steiner A. Factors influencing the attitudes of cattle veterinarians, farmers, and claw trimmers towards the pain associated with the treatment of sole ulcers and the sensitivity to pain of dairy cows. Vet J. 2014;200(1):38-43 doi: 10.1016/j.tvj1.2014.01.016. 
13. Laven R. Managing pain in lame cattle. Livestock. 2018;23(4):161-7. doi: 10.12968/live.2018.23.4.161.

14. Stilwell GT, Ferrador AM, Santos MS, Domingues JM, Carolino N. Use of topical local anesthetics to control pain during treatment of hoof lesions in dairy cows. J Dairy Sci. 2019;102(7):6383-90. doi: 10.3168/jds.2018-15820.

15. Anderson DE, Muir WW. Pain management in ruminants. Vet Clin North Am Food Anim Pract. 2005;21(1):19-31. doi: 10.1016/j.cvfa.2004.12.008.

16. Canozzi MEA, Borges JAR, Barcellos JOJ. Attitudes of cattle veterinarians and animal scientists to pain and painful procedures in Brazil. Prev Vet Med. 2020;177:104909. doi: 10.1016/j.prevetmed.2020.104909.

17. Remnant JG, Tremlett A, Huxley JN, Hudson CD. Clinician attitudes to pain and use of analgesia in cattle: where are we 10 years on? Vet Rec. 2017;181(15):400. doi: $10.1136 /$ vr. 104428 .

18. Sunilchandra U, Ravikumar C, Rashmi R. Analgesics in animal pain management. Pharma Innov. 2020;9(4):205-9.

19. Raja SN, Carr DB, Cohen M, Finnerup NB, Flor H, Gibson S, et al. The revised International Association for the Study of Pain definition of pain: concepts, challenges, and compromises. Pain. 2020;161(9):1976-82. doi: 10.1097/j.pain.0000000000001939.

20. Penning JP. Pre-emptive analgesia: what does it mean to the clinical anaesthetist? Can J Anaesth.1996;43(2):97-101. doi: 10.1007/BF03011247.

21. Fein A. Nociceptors and the perception of pain. Farmington: University of Connecticut Health Center; 2014.

22. Rossetti RB, Mastrocinque S, Macedo J. Treatment of persistent postoperative pain after ovariohysterectomy in female dogs: a comparative study between tramadol or maropitant. Rev Interdiscip Saude Educ. 2020;1(2):109-21.

23. Bond GB, Almeida R, Ostrensky A, Molento CFM. Welfare assessment methods and critical points for dairy cattle. Cienc Rural. 2012;42(7):1286-93. doi: 10.1590/S010384782012005000044.

24. Fantoni DT, Mastrocinque S. Fisiopatologia e controle da dor. In: Fantoni DT, Cortopassi SRG. Anestesia em cães e gatos. 2a ed. São Paulo: Roca; 2010. Chap. 35, p. 521-44.

25. Alimura AAS, Tognoli GK. Pathophysiology of pain and the use of morphine for analgesia in cats. REVET. 2021;6(1):1-9.

26. Lorenz MD, Coates JR, Kent M. Handbook of veterinary neurology. 5th ed. St. Louis: Elsevier Saunders; 2011. Pain; p. 413-31.

27. Moura DDMG. Pathophysiology of chronic pain [dissertation] [Internet]. Coimbra: Faculdade de Medicina, Universidade de Coimbra; 2020 [cited 2021 Abr 3]. Available from:

https://www.academia.edu/44681839/MESTRADO_INTEGRADO_EM_MEDICINA_T RABALHO_FINAL_Fisiopatologia_da_Dor_Cr\% $\bar{C} 3 \%$ B3nica_ARTIGO_DE_REVIS $\%$

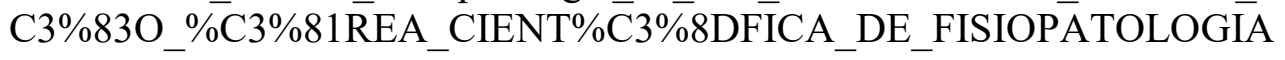

28. Teixeira FM. Comparative assessment of the effect of anti-inflammatory drugs with acupuncture on the model of post-incisional pain in rats [dissertation] [Internet]. Seropédica (RJ): Instituto de Veterinária, Universidade Federal Rural do Rio de Janeiro; 2010 [cited 2021 Abr 3]. Available from: https://tede.ufrrj.br/jspui/handle/jspui/4040 
29. Sneddon LU. Comparative physiology of nociception and pain. Physiology. 2018;33(1):63-73. doi: 10.1152/physiol.00022.2017.

30. Posso IP, Romanek RM, Gatto BEO. Dor aguda e inflamação. In: Bagatini A, CangianI LM, Carneiro AF, Nunes RR. Bases do ensino da anestesiologia. Rio de Janeiro: Sociedade Brasileira de Anestesiologia; 2017. Chap. ME 30 Ponto 50, p.1119-40.

31. Klaumann PR, Wouk AFPF, Sillas T. Pathophysiology of pain. Arch Vet Sci. 2008;13(1):1-12. doi: 10.5380/avs.v13i1.11532.

32. Oliveira Júnior JO, Portella Junior CSAP, Cohen CP. Inflammatory mediators of neuropathic pain. Rev Dor.2016;17(1):35-42. doi: 10.5935/1806-0013.20160045.

33. Aleixo GAS, Tudury EA, Coelho MCOC, Andrade LSS, Bessa ALNG. Pain treatment in small animal: physiopathology and recognition of pain (literature review: part I). Med Vet (UFRPE). 2016;10(1):19-24.

34. Silva FL, Silva CRA, Costa APR. Surgical treatment of pain in dogs and cats: Review. Vet Foco. 2011;9(1):57-75.

35. Jang Y, Kim M, Hwang SW. Molecular mechanisms underlying the actions of arachidonic acid-derived prostaglandins on peripheral nociception. J Neuroinflamm. 2020;17(1):30. doi: 10.1186/s12974-020-1703-1.

36. Zakka T, Jacobsen-Teixeira M. Dor neuropática. Diagnóstico e tratamento. Med Int Mex. 2020;36(1):9-12. doi: 10.24245/mim.v36id.3781.

37. Melzack R, Wall PD. Pain mechanisms: a new theory. Science. 1965;150(3699):971-9.

38. Melzack R, Wall PD. Textbook of pain. 4th ed. London: Churchill Livingstone; 1999.

39. Ashmawi HA, Freire GMG. Peripheral and central sensitization. Rev Dor. 2016;17(1):314. doi: 10.5935/1806-0013.20160044.

40. Coetzee JF, Shearer JK, Stock ML, Kleinhenz MD, Van Amstel SR. An update on the assessment and management of Pain Associated with lameness in cattle. Vet Clin North Am Food Anim Pract. 2017;33(2):389-411. doi: 10.1016/j.cvfa.2017.02.009.

41. Kukanich B, Wiese AJ. Opioids. In: Grimm KA, Lamont LA, Tranquilli WJ, Greene SA, Robertson SA. Lumb and Jones - veterinary anesthesia and analgesia. 5th ed. Ames: Wiley Blackwell; 2015. Chap. 11, p. 207-26.

42. Pasternak GW, Pan Y-X. Mu opioids and their receptors: evolution of a concept. Pharmacol Rev. 2013;65(4):1257-317. doi: 10.1124/pr.112.007138.

43. Anderson DE, Edmondson MA. Prevention and management of surgical pain in cattle. Vet Clin North Am Food Anim Pract. 2013;29(1):157-84. doi: 10.1016/j.cvfa.2012.11.006.

44. Coetzee JF. A review of pain assessment techniques and pharmacological approaches to pain relief after bovine castration: Practical implications for cattle production within the United States. Appl Anim Behav Sci. 2011;135:192-213. doi: 10.1016/j.applanim.2011.10.016.

45. Stock ML, Coetzee JF. Clinical pharmacology of analgesic drugs in cattle. Vet Clin North Am Food Anim Pract. 2015;31(1):113-38. doi: 10.1016/j.cvfa.2014.11.002.

46. Smith J, Coetzee JF, Fisher IWG, Borts DJ, Mochel JP. Pharmacokinetics of fentanyl citrate and norfentanyl in Holstein calves and effect of analytical performances on

Sousa FG, Souza RC, Beier SL, Barcelos BS, Araújo, KJS. Pathophysiology of pain and use of opioids in cattle. Vet. e Zootec. 2021; v28: 001-014. 
fentanyl parameter estimation. J Vet Pharmacol Ther. 2018;41(4):555-61. doi: 10.1111/jvp.12501.

47. Coetzee JF, Gehring R, Tarus-Sang J, Anderson DE. Effect of sub-anesthesic xylazine and ketamine ('ketamine stun') administered to calves immediately prior to castration. Vet Anaesth Analg. 2010;37(6):566-78. doi: 10.1111/j.1467-2995.2010.00573.x.

48. Bravo L, Mico JA, Berrocoso E. Discovery and development of tramadol for the treatment of pain. Expert Opin Drug Discov. 2017;12(12):1281-91. doi: 10.1080/17460441.2017.1377697.

49. Natalini CC, Robinson EP. Evaluation of the analgesic effects of epidurally administered morphine, alfentanil, butorphanol, tramadol, and U50488H in horses. Am J Vet Res. 2000;61(12):1579-86. doi: 10.2460/ajvr.2000.61.1579.

50. Altunkaya H, Ozer Y, Kargi E, Ozkocak I, Hosnuter M, Demirel CB, et al. The postoperative analgesic effect of tramadol when used as subcutaneous local anesthetic. Anesth Analg. 2004;99(5):1461-4. doi: 10.1213/01.ANE.0000135640.21229.A0.

51. Kamiloglu A, Kamiloglu NN, Ozturk S, Atalan G, Kilic E. Clinical assessment of epidural analgesia induced by xylazine-lidocaine combination accompanied by xylazine sedation in calves. Ir Vet J. 2005;58(10):567-70. doi: 10.1186/2046-0481-58-10-567.

52. Baniadam A, Afshar FS, Ahmadian F. Analgesic effects of tramadol hydrochloride administered via caudal epidural injection in healthy adult cattle. Am J Vet Res. 2010;71(7):720-5. doi: 10.2460/ajvr.71.7.720.

53. Naeine AT, Rezakhani A, Fazlinia J. Clinical evaluation of epidural administration of morphine, fentanyl, methadone, lidocaine and lidocaine with epinephrine in cattle. Pak Vet J. 2004;24(1):31-2.

54. Nogueira GM, Perri SHV, Santos PSP, Rodrigues CA. Pedometry applied to a comparative study using morphine and tramadol in bovine. Cienc Anim Bras. 2019;20:111. doi: 10.1590/1089-6891v20e-44627.

55. Silva LS, Ulsenheimer BC, Frank BGD, Cruz FSF, Rossi FWW, Bedendo GHM, et al. Epidural administration flow of xilazine or tramadol in cows. Braz J Anim Environ Res. 2019;2(1):482-9.

Recebido em: 07/06/2021 Aceito em: 22/11/2021 